\title{
Athena in the World of Techne: The Gender Dimension of Technology, Innovation and Entrepreneurship
}

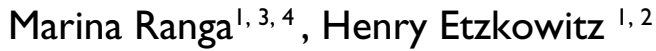

\begin{abstract}
Long confined to the realm of feminist studies, issues pertaining to women's access, participation, advancement and reward are rising to prominence in innovation, technology and entrepreneurship -areas traditionally characterised either by gender-blindness or male dominance. The implications of this shift are wide-ranging but the mechanisms by which it takes place are little known. We discuss causes of the relatively small numbers of women scientists, researchers, innovators or entrepreneurs, the exceedingly slow pace of transition from inequality to equality and the usually lower hierarchical positions than men's in academia or business, women's hidden roles in technological change and an exemplary instance of women's leading role in a major technological innovation with wide social impact, in the context of major changes arising in the transition from the Industrial to the Knowledge Society.
\end{abstract}

Keywords: gender; women; innovation; technology; entrepreneurship.

\section{About the Authors}

Marina Ranga is a Faculty Research Fellow at Stanford University's Clayman Institute for Gender Research, US, Visiting Assistant Professor at Stony Brook University New York and Visiting Fellow at Sussex University, School of Business, Management and Economics, UK. Her research interests include national and regional innovation systems, policies and strategies, Triple Helix interactions and the evolution of the entrepreneurial university, as well as the gender dimension in innovation, technology transfer and entrepreneurship. She is a member of the Gender Advisory Board of the UN Commission for Science and Technology for Development and of the UN Economic Commission for Europe's Expert Group on Innovation and Competitiveness Policies. She is the Chair of 'The gender dimension of University-IndustryGovernment interactions: Past imperfect, present tense' Plenary Session of the Triple Helix 8 International Conference (Madrid, October 2010). She co-authored 'The Coming Gender Revolution in Science' in the New Handbook of Science and Technology Studies, MIT Press, 2008 (with Etzkowitz et al) and is currently working on the book Gender Dynamics in Science and Technology: The Vanish Box Phenomenon, co-authored with Henry Etzkowitz.

\footnotetext{
I Stanford University, Michelle R. Clayman Institute for Gender Research, Stanford CA 94305, US

${ }^{2}$ Edinburgh University Business School, 7 Bristo Square, Edinburgh EH8 9AL, UK. Email: henry.etzkowitz@stanford.edu Phone: +6467012695

${ }^{3}$ Stony Brook University, Dept. of Technology \& Society, Stony Brook, New York I 1794-3760, US.

${ }^{4}$ Sussex University, School of Business, Management and Economics, Brighton, UK. Email: marina.ranga@stanford.edu

Phone: +32486626441
} 
Henry Etzkowitz is a Faculty Research Fellow at Stanford University's Clayman Institute for Gender Research, US and Visiting Professor at Edinburgh Business School, UK. He is a scholar of international reputation in innovation studies as the originator of the 'Entrepreneurial University' and 'Triple Helix' concepts that link university with industry and government at national and regional levels. He is also a leading scholar in gender in innovation studies, and co-author of an iconic book in the field Athena Unbound: The Advancement of Women in Science and Technology (Cambridge University Press, 2000). He also co-authored "The Coming Gender Revolution in Science" in The Handbook of Science and Technology Studies (MIT Press, 2008). He is currently working on a new book Gender Dynamics in Science and Technology: The Vanish Box Phenomenon (co-authored with Marina Ranga). Prior to coming to Stanford, Henry held the Chair in Management of Innovation, Creativity and Enterprise at Newcastle University Business School, UK and served as Visiting Professor in the Department of Technology and Society, Stony Brook University, US.

\section{Introduction: Why so Few? Why so Slow? Why so Low?}

To many in business, research and innovation policymaking, gender studies, as well as in the broader society, these questions are likely to be among the first that come to mind when thinking about women's participation in technology, innovation and entrepreneurship. More worryingly, these questions are still salient decades after having been raised in the 1960's, in the early days of the contemporary debate over the status of women in science and technology, when women who had reached top positions in their areas were thought to have "extraordinary motivation, thick skins, exceptional ability, and some unusual pattern of socialization in order to reach their occupational destinations" (Rossi, 1965, p. I20I). Spreading beyond the borders of science and technology, women's participation, advancement and recognition soon became matters of concern in emerging science and technology-related areas, like innovation and entrepreneurship, which were often found to replicate the discriminatory gender patterns identified in academia (Valian, 1999; Etzkowitz, Kemelgor and Uzzi, 2000).

'Why so few?', referring to the persistence of relatively small numbers of women scientists, researchers, innovators or entrepreneurs ${ }^{2}$ is inextricably related to the 'Why so slow?' reference to the exceedingly slow pace of transition from inequality to equality in these fields, and both explain our 'Why so low?' question of women's usually lower hierarchical

\footnotetext{
${ }^{2}$ For example, in 2006, on average in the EU-27, women represented $37 \%$ of all researchers in the higher education sector, $39 \%$ in the government sector, and merely $19 \%$ in the business enterprise sector (European Commission 2009), while in the US women accounted for $34 \%$ of all scientists and engineers in business or industry in the same year (NSF 2009).
}

positions than men's in academia or business. Over time, 'few' and 'slow' translate into 'low'. Overt discrimination and invisible barriers built into male-gendered systems, overcrediting men for performing traditional female roles and under-crediting women for performing traditional male roles combine to reduce the participation and advancement of women. Most efforts for change have focused on women's recruitment rather than retention and advancement, mostly due to false expectations that upward movement would take care of itself once entry was assured. It thus comes as no surprise that disproportionate numbers of women remain in low-level positions both in academia and in business, even after their presence has made itself felt for many years, inhibiting generational change as more women are recruited into science, technology, innovation and entrepreneurship careers.

'Few, slow and low' thus became the defining line for women's presence in these essential areas for progress and growth, due to strong and persisting beliefs that science and innovation operate on meritocratic and universalistic principles, where only the results obtained and the individual's contribution to knowledge matter, not the gender or the personal characteristics of the scientists, technologists and innovators who achieved them (Etzkowitz and Kemelgor, 200I). Long confined to the realm of feminist studies, issues pertaining to women's access, participation, advancement and reward are currently rising to prominence in innovation, technology and entrepreneurship - areas traditionally characterised either by gender-blindness or male dominance. The implications of this shift are wide-ranging but the intricacies of the mechanisms by which it takes place are still little known. This Special Issue reveals the workings of the subtle, but pervasive impact of gender dynamics in technological change, innovation and entrepreneurship. 


\section{Exploring the Gender Dimension in Technology, Innovation and Entrepreneurship}

Innovation theory and practice is in the midst of a shift in focus from product and process innovation, primarily in the private sector, to innovation in services that are located in the public as well as the private sector. This transition has profound consequences for the visibility of the gender dimension in innovation. The public sector, which is usually highly female-dominated and was considered to be beyond the purview of innovation, is now gaining increasing visibility in innovation theory and practice as part of the shift from an industrial to a service and knowledge economy. A possible consequence of this shifting focus to the more horizontallysegregated public sector may also be an increasing feminization in innovation research and implementation. The long-standing gendered separation of labour breaks down as men enter traditional female spheres of work and women enter traditional male spheres of employment (Etzkowitz, 1971). Although these developments are still in an early stage and are met with considerable resistance, a paradigm shift is underway where former anomalies increasingly become commonplace.

Understanding the gender consequences of this shift is challenging, because innovation studies, usually focused on teams, institutions and organizations at country or regional levels, have a poor focus on the individual innovator, and an even poorer one on the gender of the innovator, which is typically a matter of little interest and low visibility. Consequently, the gender dimension of innovation is usually considered as a peripheral element of the process, which narrowly focuses on issues like the inclusion/exclusion of women in research and development, invention and innovation. Women's role in innovation is often not seen as part of the process, even when they are a key link in the chain. For example, the role of female home economists that helped develop specific functions of the microwave oven was not acknowledged as part of the innovation process (Cockburn and Ormrod, 1993). The analysis of this supposed masculine technology that neatly reflects the technologygender relation exemplifies the re-conceptualisation of the gender dimension of technology and innovation to take account of women's contribution.

Here, we turn on its head the general perception of innovation gender-blindness due to the lack of visibility of the individual innovator in innovation policy and research. We argue that although the individual innovator is not seen in such studies, innovation is not gender-blind, but rather inherently gender-biased, because of an implicit, sociallyconstructed assumption that women are less innovative than men as a function of traditional gender relations, that men-dominated industries/sectors are more innovative than women-dominated ones, all rooted in a social perception of technology that is more often associated to men than to women. From this perspective, it also appears that "competition" is often associated with the malegendered cultural element of the innovation process, while "consensus-building" appears to be a more feminine approach. This "consensus-building" view resonates with what we have conceptualized as the Consensus Space of the Triple Helix Innovation Systems - a physical, but also a virtual space where different innovation actors come together to discuss problems, work out differences, entertain new ideas, assess blockages in the innovation environment and identify the best way forward (Etzkowitz and Ranga, 20I0). The enhanced communication processes facilitated by the Consensus Space bring to the forefront of attention underlying dimensions of innovation that may be obscured, such as the collective nature of the process, which often starts as an individual effort, but soon develops into a collective endeavour and a relationshipbuilding process that enables success.

A similar situation is found in technology, which provides a clear vertically and horizontally gender-stratified labour market, with women concentrated at the low pay, handson product making end and men at the opposite end of high pay and creative design (Rosser 2006). This was often the case when new technologies were introduced in the workplace, such as office technologies (telephones, typewriters) that required inexpensive operators, or the so-called "labour-saving household technologies" that liberated women from some domestic tasks and made them available for the labour market (Cowan, 1983). Paradoxically, new technologies offer new employment opportunities for women, but also work against them, keeping them confined to the lower, semi-skilled or unskilled positions, in the attempt to reduce the threat of women's entry into the men's sphere of work and preserve the masculine orientation towards work (see e.g. Cockburn, 1983).

Male dominance in technology not only blocks women's access to the better and higher paid jobs, but also has broader consequences that go beyond workforce structure, introducing biases in areas like health (e.g. inappropriate diagnosis and treatment) or leading to the 
creation of technologies that are useful from a male perspective, but fail to address important issues for women users. Moreover, technologies may sometimes be selected to support a male-gendered social structure even though they are less productive (Bray, 1997). This is consistent with the perception of a public sphere, with visible male roles in the production of technological innovation, along with a private sphere with obscure female support roles in the utilization of technology, as illustrated by the historical analysis of the brassiere ${ }^{3}$ and the white collar which made visible as technologies artifacts that might not usually have been considered as technological in nature (Mcgaw, 2003).

Recuperating women's traditional role in technology production and use is a useful complement to balance the analysis of technology as expressive of a dominant male ethos. A one-dimensional viewpoint runs the risk of marginalizing women by making technological competence convergent with masculinity (Brint and Gill, 1995), introducing sexual symbolism for commercial purposes (e.g. to increase automobile sales), or associating gender to rising vs. declining technologies (e.g. the early 20th century association of masculinity with the rising internal combustion engine and of femininity with the declining electric cars).. Will the return of the electric vehicle augur a feminine or a gender-neutral automotive era? As the automobile is increasingly viewed as a mere means of transportation, it may be expected that its highly male-gendered persona will decline.

In contrast to innovation, where the individual is seldom not 'seen', entrepreneurship studies place the individual in a central role, which is, however, mostly played by men. Overall, regardless of country, men are more likely to be involved in entrepreneurial activity than women. A gender gap in venture creation and ownership activity has been observed across the globe for both early stage entrepreneurial participation and established business ownership, and is greatest in the high-income country group, regardless of type of activity. In the high-income group, men are almost twice as likely to be early stage or established business owners than women (GEM 2006).

On the one hand, an often-evoked reason for women's lower likelihood to initiate new enterprises is their lower self-confidence than men's. On the other hand, it is has

${ }^{3}$ The brassiere, a cosmetic technology based on advances in textiles, introduced several innovations that have been patented. been shown that banks, venture capitalists or business angels are less likely to support female-initiated enterprises. Therefore, what appears to be a lack of confidence in women may actually be a realistic appraisal of reduced chances for success and a clear-headed approach to strategizing a way forward through the Scylla of misplaced confidence and the Charybdis of gender bias. This may explain to a large extent women's unwillingness to be entrepreneurial or at least the tendency to wait until higher level of resources have been achieved before taking the entrepreneurial plunge.

A female high-tech entrepreneur in Silicon Valley recalled how she waited until she had experience in several startups under her belt before undertaking her own, being well aware, by their track record, that male-dominated venture capital firms were less likely to fund women's ventures (Cain Miller, 2010). Indeed, when she decided to go ahead, she carefully made her pitches to firms with senior female employees and a track record of funding women's ventures in order to avoid almost certain failure. This knowledge of how to manoeuvre in a difficult gender environment enhances the chances of successes, but such awareness may not be widespread. Indeed, it may be suppressed by efforts to "gin up" confidence, rather than deal with the causes.

"Who you know" and "who knows you" still often trumps "what you know" and affects "how much you can achieve". Crowden's account of female high-tech entrepreneurs' work life shows their coping strategies, e.g. how they had to get support for their ideas in advance from male participants in meetings, even when they were senior, in order to get their ideas attended to (Crowden, 2003). Moreover, they often had to give up authorship and let men take the lead and credit to get their ideas taken up. "Whatever it takes," said one female technologist, putting the goals of her firm first, finding it necessary to accept self-effacement in order to play the game. These highly successful women were holding their own in the high-tech world, but their numbers were relatively small and their slights were typically suffered in isolation.

What is the most effective strategy to encourage women's advance in entrepreneurship? Whether to emphasize success stories to provide role models to upcoming potential female entrepreneurs or to warn of difficulties ahead and possibly discourage action is a continuing dilemma. Two narratives collide: "get on with it" and "structural exclusion". The former focuses on the 
relatively small number of female entrepreneurs and celebrates their success with the intention of encouraging others to take the leap. The latter focuses on the barriers to entry that keep female entrepreneur numbers down, as well as on policies to induce change. Female entrepreneurs may also develop alternative strategies to get around the barriers.

\section{Overcoming Male Domination Technological Innovation}

Over time, technology development has been a predominantly male enterprise, with women seldom in control of the content and direction of technological change, even when it directly affected their specific interests. Indeed, technology has been shown to typically serve as an agent of male control, through panoply of devices infused with male values, with female needs seldom taken into account (Rothschild, 1983). However, although the 'few, slow and low' overarching characteristics of women's presence in technological innovation remained largely unchanged over the last decades, recent years have seen a variety of top-down and bottom-up efforts that carried with them the seeds of change and made some progress in re-ordering the relationship of women and men to technological innovation. The traditional gendered nature of science and technology thus seems to have gradually evolved towards more gender equal formats, as specific steps have been taken to introduce women's needs into the problem choice arena, as many women's wish to balance the professional and the personal have been recognized and as inequalities in distribution of resources available for women's technological projects are at least attempted to be redressed.

For example, the pervasive spread of ICTs helped narrow the digital divide between men and women, facilitated women's work from home and gave a new impetus to the creation of female-owned businesses (UN-ECE, 2004 4 ). Computer technology can sometimes provide exceptions to prevalent gender bias as a potentially neutral area in which gender may be disguised through the creation of software agents, with the gender of the people in control hidden behind the agent's artificial persona (Haraway, 1991). While the recreation of identities in cyberspace offers intriguing possibilities for personal freedom, avatars do not challenge gendered social structures; they merely

\footnotetext{
${ }^{4}$ Available at: http://www.unece.org/gender/documents/ Overview.pdf
}

offer a temporary hiding place or respite. More typically, existing gender relations are replicated, even exaggerated in cyberspace computer games.

Another exception to the seemingly ineluctable persistence of male domination of technological innovation is the Volvo car designed by an all-women team ${ }^{5}$ aiming to meet female needs in automobile use. However, the concept car, featuring ease of entry and storage spaces designed for women's convenience was never manufactured (Temm, 2008). The project garnered considerable publicity for the firm, but turned out to be a public relations campaign in which feminist values were hijacked to provide a superficial overlay on a traditional male-gendered technology.

The development of the birth control pill is perhaps the most notable example of women's struggle and success in the world of male-dominated technologies, although women's role in this project has been underconceptualized. Although the pill, like electric lighting and the airplane had multiple sources of origination, the main line of development was through the birth control wing of the feminist movement. Margaret Sanger, a nurse, feminist activist and social entrepreneur, originated the concept of "birth control" through a pill in the early $20^{\text {th }}$ century, much as science fiction writers like Jules Verne had proposed the use of rockets for spaceflight, a concept that was taken forward by the space flight movement (Bainbridge, 1976).

The birth control movement started from the user needs of women who were desperate to control their pregnancy rate. Sanger soon realised that existing "barrier" technologies left control of pregnancy to men or at least subject to their influence, and were inadequate. She concluded that a pill that could be ingested privately met the criteria of birth control under the control of women (Chesler, 1992). Seeking out technological knowledge of contraception Sanger visited the British Library in London and then Holland where the diaphragm had been invented by a Dutch gynecologist in 184I, and on return to the US she promoted the Dutch device, helping found a firm to

\footnotetext{
${ }^{5}$ In December 2002 Volvo allowed hundreds of female employees to create a vehicle that suits their needs. Every aspect of the car's design and production has been overseen by women, a first in the automotive industry. A roomy, 2I5-horsepower coupe that was easy to park, maintain and keep clean was thus born http://www.usatoday.com/money/autos/2004-03-02-ycc x.htm, (Accessed 29 May 2010).
} 
produce it in the US. However, Sanger's ultimate objective continued to be a simple pill rather than an obtrusive device. The project reached a successful result in a relatively short time, thanks to progress in a relevant scientific field, hormonal biochemistry, which had come to maturity by the 1950's, and the contribution of two key people with both scientific skills and financial resources to support the project ${ }^{6}$.

Simultaneously, other efforts that were under way from a science push perspective also achieved success ${ }^{7}$ (Etzkowitz and Blum, 1991). At its $50^{\text {th }}$ anniversary in 2010 , the birth control pill was widely recognized as one of the leading technological innovations of the $20^{\text {th }}$ century, ranked with the airplane and the atom bomb. Nevertheless, the role of the feminist movement in its invention and diffusion is less well recognized. Most of the attention at the time of invention and thereafter has been on the male scientist inventors rather than the feminist innovators. Sanger is said to have celebrated the 1960 achievement with a solitary glass of champagne in Arizona retirement (Conlin, 2004).

\section{The Special Issue}

The theme of this Special Issue -the gender dimension in innovation, technology and entrepreneurship- is a novel research area that, with a few notable exceptions, (e.g.

\footnotetext{
${ }^{6}$ Sanger met a researcher with the appropriate skills, Dr. Gregory Pincus, Director of the Worcester Foundation for Experimental Biology, and interested him in taking on the task. She also identified a potential funder in Katherine McCormick, a 1904 biology graduate from MIT, who understood the scientific issues at hand and had the necessary funds to support the venture as heir to the International Harvester Fortune. At 75, McCormick became a research-funding angel, moving from California to be close to the research site in Massachusetts and push the research process forward.
}

${ }^{7}$ In 1951 Dr. Djerassi and his research team at Syntex in Mexico City achieved the first chemical synthesis of cortisone from a plant source, diosgenin, using Mexican Yams as the starting material to synthesize the hormones testosterone and progesterone that were needed for the production of the pill. About the same time the Upjohn Company of Kalamazoo patented an easier to achieve synthesis of cortisone starting from progesterone by a fermentation process. These developments were part of an immense international effort to find a cheaper synthesis of cortisone, the number of researchers working on this topic being greater than that of any other medical project since the development of penicillin. During the war cortisone was important to the military as it was thought to reduce stress levels in fighter pilots and after the war, cortisone was found to have anti-arthritic properties (http://www.weizmann.ac.il/ICS/booklet/ 19/pdf/Bob weintraub.pdf).
Thursby and Thursby, 2005; Link, Siegel and Bozeman, 2007) has been little explored in the literature. While there is a wealth of studies on the participation of women in science, especially academic science (Xie and Shauman, 2003; SmithDoerr, 2004; Sonnert and Holton, 2006), women's presence, identities, and advancement in innovation and technology-related professions, such as technology transfer and entrepreneurship, are only little documented.

This Special Issue presents to the scientific, business and policy-making communities a concentrated and multifaceted body of recent research that has the potential to broaden the current understanding of the dynamics and implications of technological change, inspire new research projects and disseminate good practice. The gender dimension in innovation, technology and entrepreneurship cuts across and raises new issues for research and policymaking in several related areas, such as organizational change, human resources and sustainable development. By providing relevant evidence on these areas, this Special Issue contributes to the development of both research and teaching material and the dissemination of good practice in these areas.

Several aspects of innovation, technology and entrepreneurship are addressed in this Special Issue, as follows:

\section{a) Gender in Public Services Sectors and Entrepreneurship}

Innovation policies and implementing measures have often been criticized for not acknowledging the gendered nature of the developments they promote. They have often placed a central focus on traditional men and maledominated branches of industry in the old industrial economy, primarily in the private sector, but failed to identify innovative areas in the public service economy where many women's occupations are concentrated. Also, gender equality has not been considered when evaluating the results.

In "Where are all the Female Innovators? Nurses as Innovators in a Public Sector Innovation", Nählinder addresses this gap by analysing a project aimed to bring out the potential for innovation and entrepreneurship in the public healthcare sector of nursing. The project provides a support structure -the innovation pilot scheme- to encourage nurses to invent "product innovations" in their fields and assist the inventors in 
carrying their ideas into practice. Thus, people who do not think of themselves as inventors and innovators are helped to turn from "unconscious inventors" into "conscious innovators" through the targeted intervention of the "idea pilots" and innovation advisors, who also help to fill the "confidence gap" between female and male innovators. Encouraging the nurse inventors and showing them pathways through the innovation process, instead of inventions being kept local, contributes thus to the codification of a technology transfer process, but also, most importantly, turns it into a human capital development process, whereby practitioners can become inventors and innovators.

Nählinder' findings are also relevant to entrepreneurship theory by highlighting the collective entrepreneurship dimension of the project, in addition to its innovationenhancing character. Here, innovation and entrepreneurship become a collective process, with the entrepreneurial team including the nurse as the "idea carrier", an "idea pilot" and an experienced advisor. Indeed, the three roles may be identified in iconic male entrepreneurship tales such as the founding of Apple Computer, with Wozniak the engineer as the idea carrier, Jobs, the salesman as the "idea pilot" and Markkula, the experienced semiconductor executive as the "advisor". The project demonstrates that by pairing entrepreneurs with inventors, the technology transfer process can be enhanced by removing unnecessary burdens and expectations from the inventor, who may be incapable or unwilling to fulfill them on their own, but quite willing to be part of a group process. Indeed, many inventors have little desire to take the lead in entrepreneurial ventures, but are more than willing to assist the process. The project also demonstrates that innovation and entrepreneurship are gender-biased in two major aspects: (i) femaledominated occupations such as the healthcare professions are mistakenly perceived as lacking the potential for innovation, and (ii) since innovation and entrepreneurship are traditionally conceived as individualistic activities, the potential for sharing the task is missed.

In 'Financing Strategies of New Technology-Based Firms: A Comparison of Women- and Men-Owned Firms' Robb and Coleman bring new insights on the very little explored issue of how women entrepreneurs finance their new technology-based firms. The authors investigate if women's entrepreneurship is different than men's. If so, is it by women's choice or as a consequence of differential access to resources?. The study compares owner and firm characteristics, performance outcomes and financing strategies of women- and men-owned new technologybased firms, using data from the Kauffman Firm Survey and reveals profound differences in all three areas.

Women and men owners of technology-based firms appeared to display differences in both education and experience. Women-owned new technology firms were smaller and less growth-oriented than men-owned firms, and were less likely to generate either growth or personal wealth of their owner. Nevertheless, women were more likely than men to be satisfied with their firm's performance and to be optimistic about its future, and were less driven by economic measures of success as men. In addition, women and men owners of new technologybased firms were found to use different financing strategies, either through necessity or choice: women raised significantly lower levels of capital to start their firms and less capital in subsequent years, and relied significantly more on external debt as a source of capital, while men were significantly more reliant on external equity. The choice of some types of capital rather than others appeared to be determined to some extent by women's motivations and expectations for their firms. In particular, external equity which is often associated with growth-oriented firms and requires that the entrepreneur share control and ownership appeared to be less appealing to women than to men.

In "Academic Entrepreneurship-Gendered Discourses and Ghettoes" Fältholm, Abrahamsson and Källhammer explore constructions of masculinity and femininity in discourses on academic entrepreneurship and identify the contradiction between encouraging female academic entrepreneurship and the risk to reproduce and reinforce the image of the successful male entrepreneur, instead of leading to organizational and cultural changes. The article asks how women and men academics are represented as entrepreneurs, and examines how male-gendered cultural associations are embedded in the portrayal of entrepreneurship. This may result in excluding women, placing another barrier between them and academic success, which now increasingly includes success on the entrepreneurial arena as a criterion for promotion.

The authors find that entrepreneurship-promoting texts in which only men are depicted address both women and men, while pictures of women are only targeted to women, often found in 'entrepreneurial ghettos' and conceptualized as in need of support, as less risk-willing 
and less willing to commercialize their research. While the long-term aim is to eradicate the ubiquitous division of academics into two unequally valued categories, in the shorter run a move back and forth is recommended between a liberal structuralist and social constructionist gender theory in order to develop gender mainstreaming interventions, promoting women academic entrepreneurs without reproducing gendered stereotypes.

\section{b) Gender and Technology Transfer}

As the intermediation among science and the economy becomes more significant as the basis of future economic development, women's movement into technology transfer -an emerging profession at the interface between science and industry- makes them increasingly important players in innovation. Indeed, recent evidence suggests that rising numbers of women scientists leave academia or industry to take up careers in these interface fields (Ranga et al. 2008). This phenomenon raises a plethora of questions of policy and practice relevance, such as: how does technology transfer develop as an occupational field, what does a "career" in this area mean and what gender differences does it encompass, how is the process of constructing gendered identities evolving in predominantly male-dominated work environments such as technology transfer offices and business incubators, what best practices of gender equality exist in intermediary organisations in these areas and how can they be widely disseminated to benefit the work and careers of women, etc.

In "Gender equality in interface organizations between science, technology and innovation" Vehviläinen, Vuolanto and Ylijoki analyse the internal working culture of science parks in biotechnology, engineering and social innovations (i.e. service innovations and organizational process innovations), starting from the assumption that gender patterns in science parks resemble those of the nearest academic field. They find that science parks replicate Finland's gender patterns of professional recognition and male networking specific to academia, both negatively and positively, which suggest that women do not find easy careers in science parks. Although interface work appeared to follow feminized service support patterns, it is a male-dominated field with traditional male networks facilitated by sex-segregated venues like the sauna. To counteract the persistence of these trends, women have formed their own networks in order to promote women's advancement in the field and counteract gender bias. National policy, such as provision of child care facilities, provided the basis for women's participation in the sector and mandated gender equality plans as a legitimated framework to push for change in unequal gender practices.

Achatz, Fuchs, Kleinert and Rossman's study “We are a Motley Crew: Exploring the Careers of Men and Women Working at the University-Industry Interface" looks at the technology transfer profession in Germany - a field apparently almost perfectly gender balanced on the surface, but with marked gender differences between and within technology transfer organizations. Significant differences between women and men are highlighted, regarding entry, disciplinary background and experience in the field. The authors describe three types of entry to the field: 'accidental movers' - a balanced category of men and women coming to technology transfer primarily by chance, from an academic, but mostly non-scientific background, 'strategic movers' - a predominantly male group entering the field mostly after pursuing a career in science, and 'forced movers' - an exclusively female group entering the field after a career break, most often after a "forced decision" following the impossibility of returning to a scientific career after a maternity and child rearing leave. Such women tended to view technology transfer as a "second best" alternative to a scientific research career, while men tended to view it as a useful jumping off point for a career in science-related business.

Overall, the share of women among technology transfer organizations staff in Germany appears to be higher than the share of women academics or faculty, which may be a consequence of the fact that technology transfer in such organizations is more professionalized than in German universities, and is sometimes set up to circumvent the boundaries characteristic of the public service in Germany, for example regarding legal status (limited liability companies) and salary structure - characteristics that might draw a larger pool of people to technology transfer in general, and more men in particular. The authors conclude that "technology transfer in Germany offers responsible and flexible work and the opportunity to balance career and family to all", but since it is women who almost entirely take part-time employment, it is also they who most feel the consequence of remaining limited to lower level jobs in the field. Thus, a relatively equal gender balance in technology transfer masks the structural gender bias of German society and becomes a double-edged sword. 


\section{c) Gender in ICT Professions}

Information and Communication Technologies ICT and related professions have been much trumpeted to have a great potential to create new employment opportunities for women. However, despite decades of efforts to improve it, the rate of participation of women in the sector is low, even declining, and stuck at the lower levels of the job hierarchy. Relatively little is still know about traditional vs. new ways of constructing gender identities in a field that is statistically male dominated. The evidence presented in this Special Issue provides new insights into the increasing attrition among ICT female professionals in spite of optimistic predictions of their rising numbers in the field, as well as the reasons for this decline and consequences of leaving the workplace on women's worklife balance.

In 'Women in hybrid roles in IT employment: a return to 'nimble fingers'? Glover and Guerrier plumb the depths of irony in gender-work relations through their analysis of female and male experience in the UK Information Technology (IT). The established regime of isolated technical skills is being replaced by hybrid jobs that combine technical and relational skills due to changing industry requirements. When men IT workers demonstrate the newly highly valued ability to marry soft skills to traditional IT technical tasks, they are highly rewarded for a capacity that is presumed to be exceptional. When women show the same ability, they are rewarded less for the same tasks since it is expected of them as a normal part of their gender culture. The lesson is that traditional gender rules still determine the value of job skills. Despite a revaluation of the IT industry's increased needs for traditional female skills, women still cannot win.

Griffiths and Moore's 'Disappearing Women': A study of women who left the UK ICT Sector' analyses the experiences of women who have left the sector, asks why they have departed, and tracks them to their next employment. Rather than finding the answer in the women themselves, they find it in the alienating workplace environment that they have experienced. Reasons why the 'disappearing women' did not want to stay in ICT or could not get back into ICT included workload and long hours, ostracizing and hostilities, ageism, dual roles and/or relocation. Their postICT career paths included a nutritionist, a bereavement counselor, a hypnotherapist, with two moving into education, and one women having aspirations to be a life- coach. Is it surprising that since these women's experience in ICT was so alienating, they sought professional opportunities as far from ICT as possible?

In 'Gender implications on the Information Society' SanchezGalvis sounds a more optimistic note on the demand side. She provides an empirical picture of gender differences in Internet use in Latin America. Significantly the differences between men and women's Internet use are relatively small, even as the overall rates of usage vary considerably among countries. Moreover, urban rural patterns with small gender differences show consistencies across countries as do age differences, with the 15-24 age group at the peak and the over 65's the lowest. In a few countries, for example, Panama, female Internet usage is slightly higher than male in certain segments of the population. Overall, Internet use is a beacon of equality between the genders in Latin America.

\section{d) Gender Patterns in Technology and Engineering Research: From National Focus to Pan-European and Beyond}

Exploring the gendering of excellence in technology and engineering research has become a key issue on the agenda of European policy-makers due to the strong position this field enjoys in national, European and international research policy and also because it continues to be the most male-dominated research field. Current attempts to promote scientific excellence in Europe can no longer ignore the gender aspects of research organizations, managers, programmes, policies and outcomes. The combination of scientific excellence with the promotion of gender equality has become a central challenge for gendersensitive science and research policy. Mainstreaming gender equality has been introduced in many countries as an instrument to reduce or remove gender bias, through measures to integrate gender equality into all policy areas, scrutinizing social constructions of gender and their implications for women and men respectively.

Husu and Koskinen's paper 'Gendering excellence in technological research: A comparative European perspective' reflects this growing effort in Europe and beyond. They report on the EU Framework Programme 6-funded research project PROMETEA on empowering women in technological research. The project assessed women's participation in technological and engineering research in the EU27, Russia and Chile, and focused on research funding, publishing, scientific prizes and awards, and patents. 
Gender issues appeared to be a little concern in most areas of excellence in engineering and technological research in most countries studied.

Large gaps were found in data availability by gender in most countries and organisations. Systematic gender monitoring appeared to be rare with a few exceptions, such as the Swedish and Finnish Research Councils. No national patent authority was found to perform gender monitoring on patent applicants and awards on a regular basis. Male dominance was heaviest in editorial positions of top international engineering journals and among decisionmakers and recipients of the most significant international technology prizes and awards, where hardly any women were involved. On the other hand, policy intervention has brought about a larger representation of women in top research management and leadership positions in public funding organizations, although significant country differences were observed. In general, male domination of technology and engineering was found to be result of a triple effect: (i) male dominance in most technology and engineering fields, both numerically and in leadership positions; (ii) processes of homosociality, inclusion and exclusion in both the control, gate-keeping and decisionmaking on excellence, and the award of excellence itself; and (iii) the increasing internationalization of networks, organisations and institutions that introduce social gendered relations at the local, national, disciplinary and professional levels. Recommendations are made to improve women's participation by broadening recruitment from academia, where the proportion of women in high positions is low, to industry and government.

\section{e) Gender and Career Breaks in Academia}

The difficulties faced by women academics returning to work after a career break, most often taken for maternity or elderly care reasons, are one of the many causes for the low numbers of women, particularly in the higher positions. Forced choices of career gaps or part-time employment are viewed negatively and taken as evidence of "un-seriousness", ultimately working against women's progression in academic careers.

In "Mind the Gap: Women in STEM Career Breaks" Mavriplis et al. examine the pressures that determined 15 women $\mathrm{PhDs}$ in science, technology, engineering and mathematics (STEM) to take career breaks, if/how they remained connected (or not) to their field during breaks and the difficulties they met re-entering the field after the break.
The authors find that the usual pattern of a lock-step career academic progression from undergraduate to graduate education, to a post-doc position and then to an academic position with continuous employment, especially as relates to tenure-track positions, disproportionately penalises women and contributes to their slow professional advancement.

Based on the interviews and other data, Mavriplis et al propose several interim measures to facilitate re-entry. Most important is the need for strong support on the part of university leadership regarding the validity of taking time off to have a family and return or to work on a part-time basis for a limited period of time. Nevertheless, changing the structure of academic science to allow non-linear careers is seemingly beyond the realm of viable proposals: "There are no visible successful examples of non-linear careers for STEM women. Only non-breaking careers are publicized as successful examples." On the other hand, universities are increasingly willing to extend leave procedures to academics involved in high-tech firm formation. Perhaps similar accommodations could be made for family-formation?

The Special Issue concludes with Abir-Am's "Gender and TechnoScience: A Historical Perspective", which takes the achievement of parity in receipt of Nobel prizes by women and men during the most recent round of awards as a potential "turning point" in the relationship of gender and science, a troubled interaction from the Scientific Revolution to the present. Women's exclusion and marginalization has only been gradually overcome, with women gaining entry to scientific careers, initially through family ties and then through the creation of female colleges. Wartime exigencies provided only a temporary respite from discrimination. Pressure from an international feminist movement has led to legal changes in which overt discrimination was delegitimized only to be replaced by more subtle forms of covert discrimination. The 2005 controversy ignited at Harvard University by the comments of its then President Lawrence Summers brought into the sunlight the hidden negative beliefs of a significant portion of the male scientific establishment of their female peers. The strong response to this unexpected revelation may signal a change in theory as well as practice in behaviour of the scientific establishment, suggested by a recent increase in inclusion of women in the ranks of the National Academy of Sciences. 
Whether Abir-Am's relatively optimistic vision of the future of women in techno-science from her historical perspective "holds water" will be determined by revision in the taken-for-granted career structures of academic science that work against the promotion of younger women faced with the contradiction between the biological clock and the tenure track in US academia. Other academic systems, lacking such sharp break points, nevertheless have their own hidden restrictive patterns, even in European social welfare states. Ironically, Europe looks to the US for models to promote the advancement of women in science. Whether the glass is half empty or half full is still a matter of debate (Etzkowitz, 2007). Nevertheless, the singular achievement of gender parity in the most distinguished of all scientific awards is a matter for celebration.

\section{References}

BAINBRIDGE, W. (1976). The Spaceflight Revolution. Wiley Interscience, New York.

BRAY, F. (1997). Technology and Gender: Fabrics of Power in Late Imperial China. University of California Press, Berkeley and Los Angeles.

CAIN MILLER, C. (2010). Out of the loop in Silicon Valley. New York Times, 18 April 2010

CHESLER, E. (1992). Woman of Valor: Margaret Sanger and the Birth Control Movement in America. Simon \& Schuster, New York.

COCKBURN, C. (1983). Brothers: male dominance and technological change. Pluto Press, London.

COCKBURN, C., Ormrod, S. (1993). Gender and Technology in the Making. Sage Publications, London.

CONLIN, M. (2004). Margaret Sanger: Birth Control of a Nation. I 3 September 2004 http://www.businessweek.com/ magazine/content/04_37/b3899026_mz072.htm (Accessed I June 2010).

COWAN SCHWARZ, R. (1983). More work for Mother: The ironies of household technologies from the Open Hearth to the Microwave. Basic Books, New York.

CROWDEN, N. (2003). Examining Gender Bias in Studies of Innovation. MA Thesis. Simon Fraser University, Burnaby B.C.
EUROPEAN COMMISSION (2009). She Figures 2009. Statistics and Indicators on Gender Equality in Science. http:// ec.europa.eu/research/science-society/document library Ipdf_06/she_figures_2009_en.pdf (Accessed I June 2010)

ETZKOWITZ, H., Blum, E. (1997). Entrepreneurial Science in Mexico as a Development Strategy". Sociology of Science Yearbook. Kluwer Academic Publishers, Dordrecht.

ETZKOWITZ, H., Kemelgor, C., Uzzi, B. (2000). Athena Unbound: The Advancement of Women in Science and Technology. Cambridge University Press, Cambridge.

ETZKOWITZ, H., Kemelgor, C. (200I). Gender inequality in science: A universal condition? Minerva, 39(2), 239-257.

ETZKOWITZ, H., Ranga M. (20I0). A Triple Helix System for Knowledge-based Regional Development: From "Spheres" to "Spaces". Theme paper for Triple Helix 8 International Conference, Madrid, October 2010, http://www.triplehelix8.org/downloads/Theme-Paper.pdf

ETZKOWITZ, H. (197I). The male nurse: Sexual separation of labour in society. Journal of Marriage and the Family, August 1971.

ETZKOWITZ, H (2007). The Athena Paradox: Bridging the Gender Gap in Science. Journal of Technology Management and Innovation, 2(I), I-3.

FAULKNER, W. (2000). The Power and the Pleasure? A Research Agenda for "Making Gender Stick" to Engineers. Science, Technology and Human Values, 25(I), 87-II9.

GLOBAL ENTREPRENEURSHIP MONITOR (GEM) (2006). Report on Women and Entrepreneurship. http://www.gemconsortium.org/document.aspx?id=580

(Accessed I June 2010).

GRINT, K., Gill, R. (1995). The gender-technology relation: contemporary theory and research. Taylor and Francis, London.

HARAWAY, D. (1991). A Cyborg Manifesto: Science, Technology, and Socialist-Feminism in the Late Twentieth Century. In: Simians, Cyborgs and Women: The Reinvention of Nature. Routledge, New York.

KOHLER, R. (1994). Lords of the Fly. University of Chicago Press, Chicago. 
LINK, A.N., Siegel D.S., Bozeman, B. (2007). An empirical analysis of the propensity of academics to engage in informal university technology transfer. Industrial and Corporate Change, 16(4), 64I-655.

MCGAW, J. (2003). Why feminine technologies matter? In: Lerman, N., R. Oldenziel, Mohun A. (eds) Gender and Technology: A Reader. Johns Hopkins University Press, Baltimore.

MILLS, E. (2009). Women have got greedy with maternity leave. The Sunday Times, October 18.

NSF (2009). Women, Minorities, and Persons with Disabilities in Science and Engineering http://www.nsf.gov/statistics/ wmpd/figh-4.htm (Accessed I June 2010).

RANGA, M., Etzkowitz, H., et al. (2008). Gender Patterns in Technology Transfer: Social innovation in the making? Research Global, 4-5.

ROSSER, S.V. (2006). Women, Men and Engineering. In: Frank Fox, M., Johnson, D.G., Rosser, S.V. (eds) Women, Gender and Technology. University of Illinois Press.

ROSSI, A. (1965). 'Women in Science: Why So Few?' Science, 148, I196-1203.

ROTHSCHILD, J. (1983). Machina Ex Dea: Feminist Perspectives on Technology. Pergamon, New York.

SMITH DOERR, L. (2004). Women's Work: Gender Equality vs. Hierarchy in the Life Sciences. Lynne Rienner, Boulder CO.

SONNERT, G., Holton, G. (2006). Who Succeeds in Science? The Gender Dimension. Rutgers University Press, New Brunswick.

THURSBY, J.G., Thursby M.C. (2005). Gender Patterns of Research and Licensing Activity of Science and Engineering Faculty. Journal of Technology Transfer, 30(4), 343-353.

TEMM, T. (2008). If you meet the expectations of women, you exceed the expectations of men: How Volvo designed a car for women customers and made world headlines. In: Schiebinger, L. (ed.) Gendered Innovations in Science and Engineering. Stanford University Press, Stanford.
UNITED NATIONS ECONOMIC COMMISSION FOR EUROPE (2004). Access to financing and ICT for women entrepreneurs in the UNECE region. Challenges and good practices. Geneva and New York.

VALIAN, V. (1999). Why so Slow? The Advancement of Women. MIT Press, Cambridge.

XIE, Y., Shauman, K.A. (2003). Women in Science: Career Processes and Outcomes. Harvard University Press, Cambridge, MA. 